\title{
Report of Trematosoma rotunda (Ciliophora, Suctorea) as epibiont on harpacticoid copepod from western Indian coast
}

\author{
TAPAS ChatTERJEE, ${ }^{1}$ IGOR DOVGAL, ${ }^{2}$ MAHESH JADHAV, ${ }^{3}$ MANDAR NANAJKAR ${ }^{4}$ \\ ${ }^{1}$ Near Harimandir Road, Dhanbad 826001, Jharkhand, India, ORCID: 0000-0001-5532-2726 \\ 2 A.O. Kovalevsky Institute of Biology of the Southern Seas of Russian Academy of Sciences, 2, Nakhimov ave, Sevastopol, 299011, \\ Russia, ORCID: 0000-0002-3876-233X \\ ${ }^{3}$ CSIR - National Institute of Oceanography, Dona Paula, Goa, 403004, India, ORCID: 0000-0003-4867-3661 \\ ${ }^{4}$ CSIR - National Institute of Oceanography, Dona Paula, Goa, 403004, India, ORCID: 0000-0002-6608-7669 \\ Corresponding authors: e-mail: drtchatterjee@yahoo.co.in
}

Keywords epibiont ciliate, copepod, India, Arabian Sea

Abstract Suctorian ciliate Trematosoma rotunda (Allgén, 1952) is reported here for the first time as epibiont on a harpacticoid copepod collected from Mandovi river estuarine mouth, Goa, west coast of India, Arabian Sea. The description of the species, synonymy, data on species distribution and host taxa are also presented in this study.

Notatka o Trematosoma rotunda (Ciliophora, Suctorea) jako epibioncie występ[ującym na Herpacticoida z zachodniego wybrzeża Indii

Słowa kluczowe epibiontyczne orzęski, oczliki, Indie, Morze Arabskie

Streszczenie Po raz pierwszy odnotowano gatunek orzęska Trematosoma rotunda (Allgén, 1952) jako epibionta na Herpacticoida zebranym z ujścia rzeki Mandovi, Goa, zachodnie wybrzeże Indii, Morze Arabskie. W pracy przedstawiono opis gatunku, synonimizację oraz dane dotyczące rozmieszczenia gatunków i taksonów żywicieli.

\section{Introduction}

Suctorian ciliates are common epibionts of marine meiobenthic invertebrates such as nematodes, halacarid mites, harpacticoid copepods, kinorhynchs, ostracods, bryozoans etc. (eg., Precht, 1935; Jankowski, 1981; 2007; Dovgal, 2002; 2013; Dovgal et al., 2008; 2009; Fernandez-Leborans, Tato-Porto, 2000a, b; Ingole et al., 2010; Fernandez-Leborans et al., 2012; Chatterjee et al., 1996; 2012; 2013a, b, c; 2014a, b; 2018; 2019a, b, c; 2020a, b, c, d, e, f; Durucan, 2019).

Trematosoma rotunda (Allgén, 1952) a marine loricate suctorian ciliate described by Allgén (1952) as epibiont on marine nematodes Desmodorella tenuispiculum (Allgén, 1928) and 
Croconema stateni Allgén, 1928 collected in the Antarctic (Graham Land) and the Falkland Islands, was named as Acineta rotunda. In the same paper another suctorian species (Acineta ovoidea) inhabiting on nematodes was described. However, Curds (1985) synonymized A. ovoidea with $A$. rotunda showing that $A$. ovoidea was nothing but lateral view of $A$. rotunda. Dovgal (2002) transferred $A$. rotunda into genus Trematosoma Batisse, 1972 based on arrangement of its tentacles in two rows.

Dovgal et al. (2009) reported this species on the nematode Pseudochromadora sp. collected near Ratnagiri, Maharastra State, central west coast of India (Arabian Sea), and provide detailed remarks on the systematics and nomenclature of this species.

Fisher (2003) found epibiont ciliate on nematode Pseudochromadora cazca Gerlach, 1956, from the intertidal zone of North-Eastern Queensland, Australia; Dovgal et al. (2009a) identified this species based on Fisher's photo 'probably as Trematosoma rotunda (Allgén, 1952)'.

Bhattacharjee (2014), Ansari and Bhaduri (2016), Ghosh and Mandal (2019) reported the same species on the nematode host from Bay of Bengal, Indian Ocean. Baldrighi et al. (2020) found this species on nematode from NW Madagascar margin-deep sea pockmark and Gulf of Naples-shallow vent area.

We report here T. rotunda from Goa, west coast of India, Arabian Sea as an epibiont on harpacticoid copepod.

\section{Material and Methods}

Samples were collected from Mandovi river estuarine mouth $\left(15^{\circ} 28^{\prime} 43.68^{\prime \prime} \mathrm{N}\right.$ and Long $73^{\circ} 41^{\prime} 41.28^{\prime}$ E), Goa, west coast of India, Arabian Sea (Figure 1) at 20m depth. Samples were sieved in the laboratory using $45 \mu \mathrm{m}$ mesh size sieve. Infested meiofauna were sorted, mounted on a 50\% glycerine slide and sealed with DPX. The systematic position of suctorian ciliates follows Dovgal $(2002 ;$ 2013). Measurements were carried out on four specimens using the program Toup View 3.7 for digital camera. Specimens are kept in the collection of the fourth author (MN) in CSIR - National Institute of Oceanography, Dona Paula, Goa.

\section{Result and Discussion}

Class Suctorea Claparéde and Lachmann, 1859

Subclass Endogenia Collin, 1012

Order Acinetida Raabe, 1964

Family Acinetidae Ehrenberg, 1834

Genus Trematosoma Batisse, 1972

Trematosoma rotunda (Allgén, 1952) (Figure 2A-C)

=Acineta rotunda Allgén, 1952

=Nematacineta rotunda (Allgén, 1952)

=Conchacineta rotunda (Allgén, 1952)

=Acineta ovoidea Allgén, 1952 


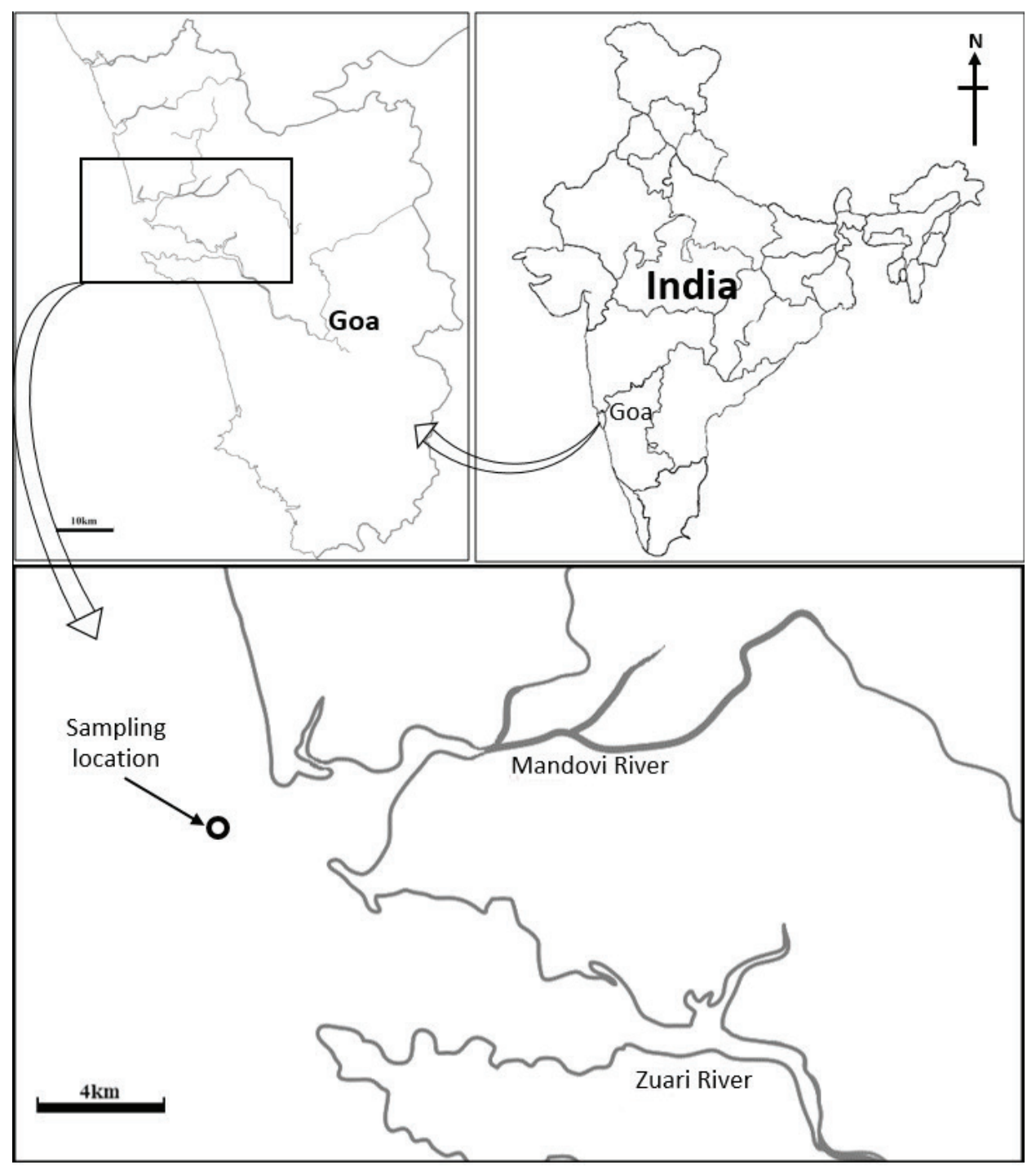

Figure 1. Map of collection site 


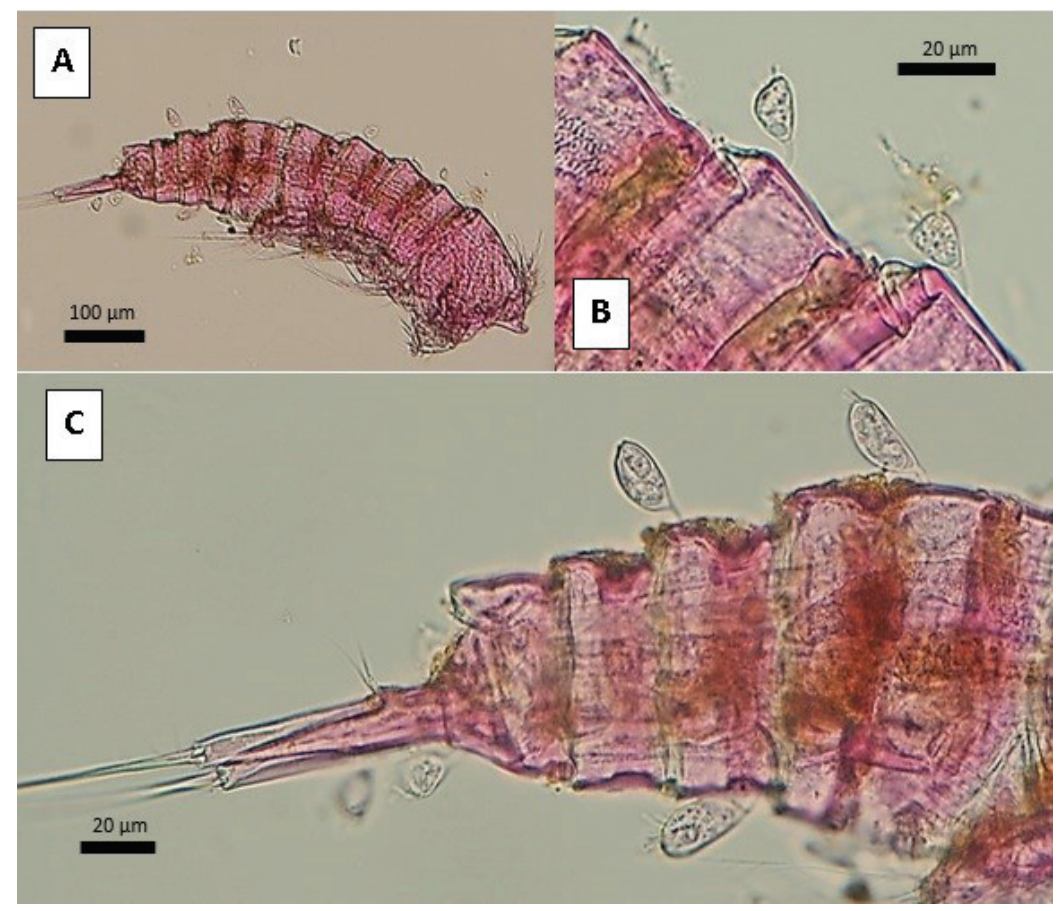

Figure 2. Trematosoma rotunda on harpacticoid host body

Material examined: Several individuals distributed throughout the harpacticoid copepod body.

\section{Diagnosis}

Marine loricate suctorian. Cell body short, rounded, laterally flattened, entirely fills up the lorica and clamped to their aperture border. Lorica delicate gently striated. Tentacles clavate, short, arranged in two groups of rows at the upper body surface. Macronucleus spherical or oval, centrally or slightly posteriorly located. Stalk short, thin, slightly ribbed.

\section{Measurements}

Morphometric measurements of specimens of Trematosoma rotunda observed in the present study (based on 4 individuals, in $\mu \mathrm{m}$ ): Lorica length 12-27, lorica width 8-9, body length 11-17, body thickness 8 , macronucleus diameter 3-6, stalk length 3-8, stalk diameter 1-3, length of tentacles 2-5; protomite length 7, width 3 .

\section{Distribution and host specificity}

Table 1 shows both the basibiont species and known localities of T. rotunda, while Figure 3 illustrated the map of the species distribution. 


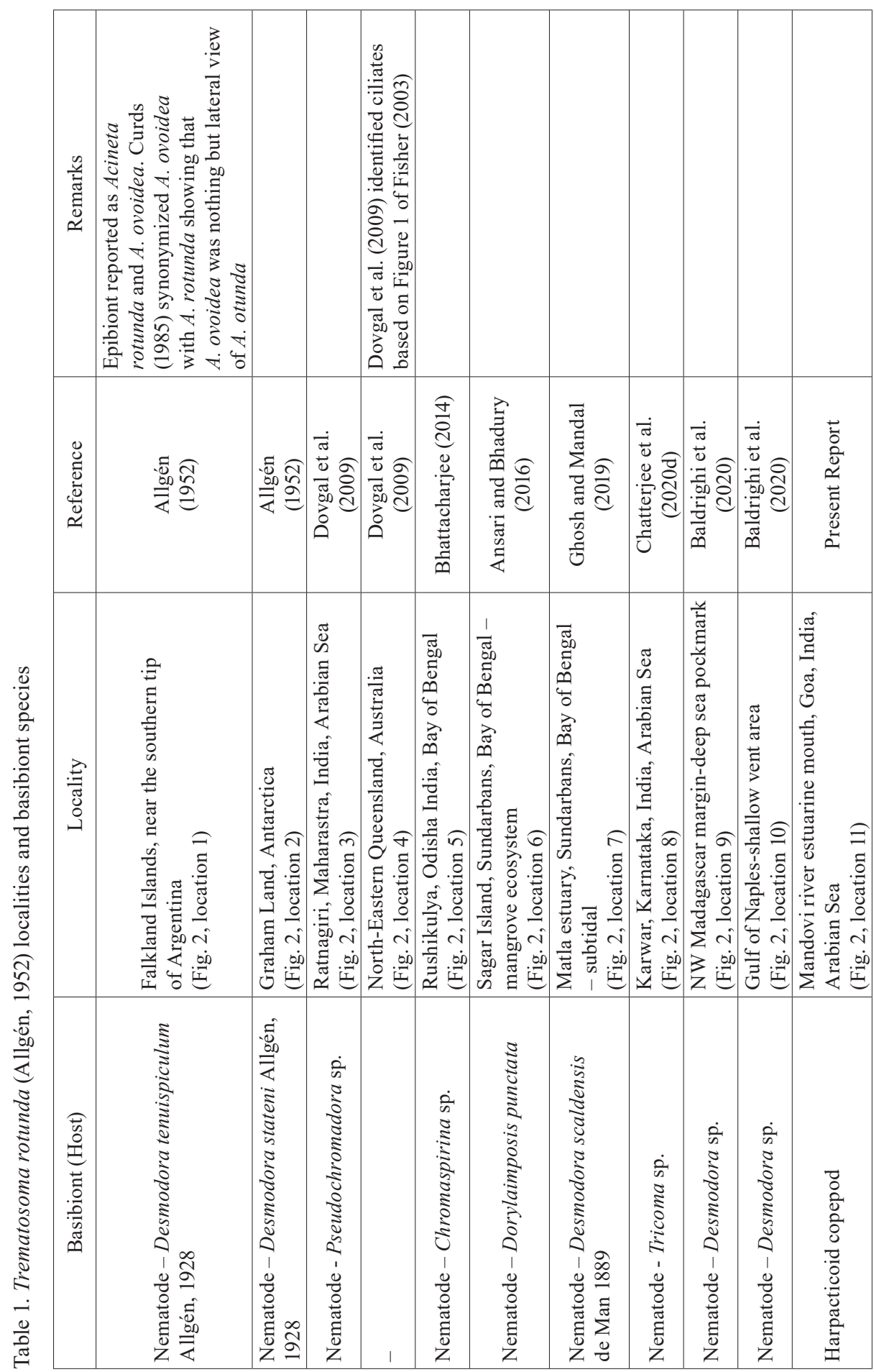




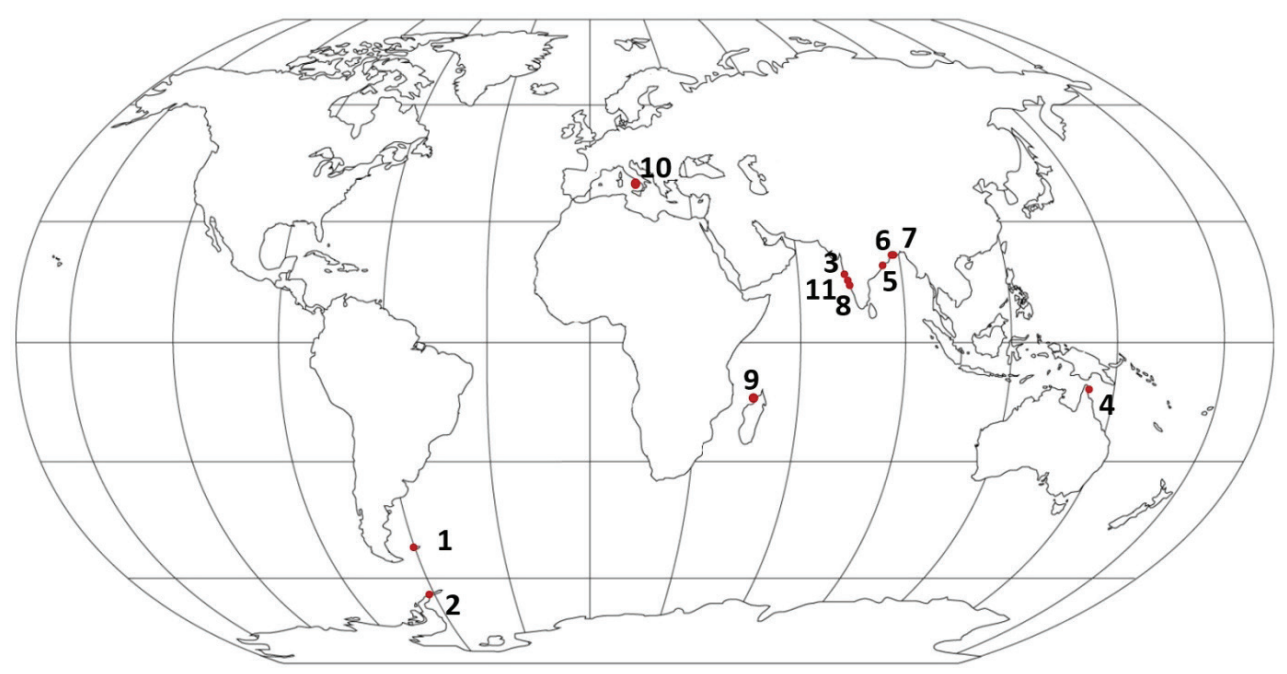

Figure 3. The map of world distribution of Trematosoma rotunda (the numbers of localities correspond to Table 1)

It should be presumed that the species is widely distributed, whose spread may be limited possibly by salinity. The relatively small number of finds of the species is apparently associated with a lack of research interest to ciliate epibiosis. This species was predominantly found on nematodes. Chatterjee et al. (2019b) have previously mentioned about $T$. rotunda, which most likely epibiont on nematodes only. However, our new finding is not only the first report of this species from Goa, but the first its registration on representative of new host taxon - Harpacticoida Sars, 1903. The last finding permits to conclude that $T$. rotunda may inhabit on a wide range of meiobenthic marine invertebrates.

\section{Acknowledgement}

The 2nd author's (Igor Dovgal) work was made within the framework of research issue of A.O. Kovalevsky Institute of Biology of the Southern Seas of RAS\#AAAA-A19-119060690014-5. The $3^{\text {rd }}$ and $4^{\text {th }}$ author's (Mahesh Jadav and Mandar Nanajkar) work was made under the project GAP3196.

\section{References}

Allgén, C.A. (1952). Uber zwei neue antarktische Suctorien aus dem Gracham Land. Kungliga Fysiografiska Sallskapets i Lund Forhandlingar, 121, 173-176.

Ansari, K.G.M.T., Bhadury, P. (2016). Occurrence of epibionts associated with meiofaunal basibionts from the world's largest mangrove ecosystem, the Sundarbans. Marine Biodiversity, 47, 539-548.

Baldrighi, E., Dovgal, I., Zeppilli, D., Abibulaeva, A., Michelet, C., Michaud, E., Franzo, A., Grassi, E., Cesaroni, L., Guidi, L., Balsamo, M., Sandulli, R. and Semprucci, F. (2020). The cost for biodiversity: 
records of ciliate-nematode epibiosis with the description of three new suctorian species. Diversity, 12 (6), 25. DOI: 10.3390/d12060224.

Bhattacharjee, D. (2014). Suctorian epibionts on Chromaspirina sp. (Nematoda: Desmodoridae) from the shallow continental shelf of the Bay of Bengal, northern Indian Ocean. Marine Biodiversity Records, 7 (e49), 1-3.

Chatterjee, T. (1996). Ciliate infestation on the phytal Halacaridae (Acari) from the Kovalam beach, Kerala. Journal of the Bombay Natural History Society, 93, 107-108.

Chatterjee T., Fernandez-Leborans, G., Chan, B.K.K. (2012). New record of ciliate Thecacineta calix (Ciliophora: Suctorea) epibiont on Agauopsis halacarid mite (Acari, Halacaridae) from Taiwan. Scripta Scientarium Naturalium, 2, 121-127.

Chatterjee, T., Fernandez-Leborans, G., Ramteke, D., Ingole, B. (2013a). New records of epibiont ciliates (Ciliophora) from Indian coast with descriptions of six new species. Cahiers de Biologie Marine, 54, 143-159.

Chatterjee, T., Fernandez-Leborans, G., Senna, A.R. (2013b). Ciliate epibionts on Melita petronio Senna et al., 2012 (Crustacea: Amphipoda) from Brazil. Cahiers de Biologie Marine, 54, 393-404.

Chatterjee, T., Kotov, A., Fernandez-Leborans, G. (2013c). A checklist of epibiotic ciliates (Peritrichia and Suctoria) on the cladoceran crustaceans. Biologia, 68, 439-477. DOI: 10.2478/s11756-013-0180-8.

Chatterjee, T., Fernandez-Leborans, G., Schizas, N.V. (2014a). Report of Thecacineta calix (Ciliophora: Suctorea) as an epibiont of harpacticoid copepods from Caribbean mesophotic reefs. Caribbean Journal of Science, 48, 44-48.

Chatterjee, T., Fernandez-Leborans, G., Marshall, D.J. (2014b). New records of ciliate epibionts (Ciliophora: Suctorea) from Brunei Darussalam. Marine Biodiversity Records, 7 (e87), 1-4.

Chatterjee, T., Dovgal, I., Pésic, V., Zawal, A. (2018). A checklist of epibiont suctorian and peritrich ciliates (Ciliophora) on halacarid and hydrachnid mites (Acari: Halacaridae \& Hydrachnidia). Zootaxa, 4457, 415-430. DOI: 10.11646/zootaxa.4457.3.4.

Chatterjee, T., Nanajkar, M., Dovgal I. (2019a). New record of Loricophrya stresemanni (Ciliophora, Suctorea) as epibiont on nematodes from the Indian Ocean and notes on the genus Loricophrya. Cahiers de Biologie Marine, 60, 283-288. DOI: 10.11646/zootaxa.4612.4.2.

Chatterjee, T., Dovgal, I., Fernandez-Leborans, G. (2019b). A checklist of suctorian epibiont ciliates (Ciliophora) found on aquatic meiobenthic nematodes. Journal of Natural History, 53, 2133-2143. DOI: 10.1080/00222933.2019.1692085.

Chatterjee, T., Nanajkar, M., Dovgal, Sergeeva, N., I., Bhaves, N. (2019c). New records of epibiont Thecacineta calix (Ciliophora, Suctoria) from the Caspian Sea and Angria Bank, Arabian Sea. Cahiers De Biologie Marine, 60 (5), 445-451. DOI: 10.21411/CBM.A.C75BCBEA.

Chatterjee, T., Dovgal, I., Mayen-Estrada, R., Fernandez-Leborans, G. (2020a). A checklist of ciliates (Ciliophora) inhabiting on ostracods (Crustacea, Ostracoda). Zootaxa, 4763 (1), 17-30. DOI: 10.11646/ zootaxa.4763.1.2.

Chatterjee, T., Dovgal, I., Nanajkar, M. (2020b). New records of epibiont ciliates Thecacineta urceolata and Acinetides gruberi (Ciliophora: Suctorea) from the Indian coast. Cahiers De Biologie Marine, 61 (3), 355-360. DOI: 10.21411/CBM.A.B713B863.

Chatterjee, T., Dovgal I., Nanajkar, M. (2020c). A new species of the genus Corynophrya (Ciliophora: Suctorea) from the west coast of India, Arabian Sea. Cahiers De Biologie Marine, 61 (4), 423-428. DOI: 10.21411/CBM.A.BE53B2AD.

Chatterjee, T., Dovgal, I., Nanajkar, M. (2020d). Report of ciliate epibionts (Ciliophora, Suctorea) on meiobenthic invertebrates from the Indian coast near Karwar, Karnataka. Protistology, 14 (2), 84-88. 
Chatterjee, T., Dovgal, I., Vieira, L.M., Dutta, A., Nanajkar, M. (2020e) Report of ciliate-bryozoan-crustacean hyperepibiosis on crab (Decapoda: Brachyura) from west coast of India, Arabian Sea. Zootaxa, 4890 (3), 347-360. DOI: 10.11646/zootaxa.4890.3.3.

Chatterjee, T., Dovgal, I. (2020f). A checklist of ciliate epibionts found on bryozoans. Zootaxa, 4896 (4), 547-559. DOI: 10.11646/zootaxa.4896.4.6.

Curds, C.R. (1985). A revision of Suctoria (Ciliophora, Kinetofragminofora) 1. Acineta and its morphological relatives. Bulletin of the British Museum (Natural History), Zoology series, 48, 75-129.

Dovgal, I.V. (2002). Evolution, phylogeny and classification of Suctorea (Ciliophora). Protistology, 2 (4), $194-270$

Dovgal, I.V. (2013). Fauna of Ukraine. Vol. 36. Ciliates-Ciliophora. Issue 1. Class Suctorea. Kiev: Naukova dumka.

Dovgal, I., Chatterjee, T., Ingole, B., Nanajkar, M. (2008). First report of Limnoricus ponticus Dovgal and Lozowskiy (Ciliophora, Suctorea) as epibionts on Pycnophyes (Kinorhyncha) from Indian Ocean with key to species of the genus Limnoricus. Cahiers De Biologie Marine, 49, 381-385.

Dovgal, I., Chatterjee, T., Ingole, B. (2009). New records of Thecacineta cothurnioides and Trematosoma rotunda (Ciliophora, Suctorea) as epibionts on nematodes from Indian Ocean. Protistology, 6 (1), $19-23$.

Durucan, F. (2019). First record of Thecacineta calix (Ciliophora: Suctoria) on harpacticoid copepod from Aegean Sea, Turkey. Acta Biologica, 26, 31-34. DOI: 10.18276/ab.2019.26-03.

Fernandez-Leborans, G., Tato-Porto, M.L. (2000a). A review of the species of protozoan epibionts on crustaceans. I. Peritrich ciliates. Crustaceana, 73, 643-684. DOI: 10.1163/156854000504705.

Fernandez-Leborans, G., Tato-Porto, M.L. (2000b). A review of the species of protozoan epibionts on crustaceans. II. Suctorian ciliates. Crustaceana, 73, 1205-1237. DOI: 10.1163/156854000505209.

Fernandez-Leborans, G., Chatterjee, T., Grego, M. (2012). New records of epibiont ciliates (Ciliophora) on Harpacticoida (Copepoda, Crustacea) from the Bay of Piran (Gulf of Trieste, Northern Adriatic). Cahiers de Biologie Marine, 53, 53-63.

Fisher, R. (2003). Ciliate hitch-hikers-nematode ecto-commensals from tropical Australian seagrass meadow. Journal of the Marine Biological Association, U.K., 83, 445-446. DOI: 10.1017/ S0025315403007306h.

Ghosh, M., Mandal, S. (2019). Living with nematode: an epibiont Trematosoma rotunda associated with basibiont Desmodora scaldensis from Matla Estuary, Sundarbans, India. Thalassas, An International Journal of Marine Sciences, 35, 619 -624. DOI: 10.1007/s41208-019-00129-3.

Ingole, B., Singh, R., Sautya, S., Dovgal, I., Chatterjee, T. (2010) Report of epibiont Thecacineta calix (Ciliophora, Suctorea) on deep sea Desmodora (Nematoda) from the Andaman Sea, Indian Ocean. Marine Biodiversity Records, 3 (e46), 1-3. DOI: 10.1017/S1755267209990777.

Jankowski, A.V. (1981). New species, genera and families of tentacle infusoria (class Suctoria). Proceedings of the Zoological Institute, 107, 80-115.

Jankowski, A.V. (2007). Review of taxa Phylum Ciliophora Doflein, 1901. In: Protista: Handbook on Zoology. Pt. 2 (pp. 415-993) (A.F. Alimoved). St. Petersburg: Nauka.

Precht, H. (1935). Epizoen der Kieler Bucht. Nova Acta Leopoldina, 3, 405-474.

Cite as: Chatterjee, T. Dovgal, I., Jadhav, M., Nanajkar, M. (2020). Report of Trematosoma rotunda (Ciliophora, Suctorea) as epibiont on harpacticoid copepod from western Indian coast. Acta Biologica, 27, 109-116. DOI: 10.18276/ab.2020.27-10. 